\title{
NEWLY DEVELOPED AI-Si BASED ALLOY FOR HIGH TEMPERATURE PROCESSES IN AUTOMOTIVE
}

\author{
Jaromír CAIS, Klára CAISOVÁ \\ UJEP-Jan Evangelista Purkyne University, Usti nad Labem, Czech Republic, EU, \\ jaromir.cais@ujep.cz,klara.caisova@ujep.cz
}

https://doi.org/10.37904/metal.2020.3582

\begin{abstract}
Silumins (Al-Si alloys) are the most used type of aluminum foundry alloys used in the automotive. Their significant expansion is result of unique properties combination. The requirements of current automotive industry bring demands for high mechanical properties of silumins (mostly by high temperature processes, which decrease properties of aluminum alloys). One area of application where silumins replace the Fe based alloys are forms for tires pressing. Working temperature during this casting process is $160-180{ }^{\circ} \mathrm{C}$, but nowadays trends for rubber vulcanization in tires production increase working temperature over $200{ }^{\circ} \mathrm{C}$. Ordinary aluminum alloys lose their mechanical properties at this temperature.
\end{abstract}

The article describes results of research of newly developed alloy applied for tire pressing forms. This research was subsequently widened by heat treatment being applied to this alloy. Both of these material characteristics (chemical composition and heat treatment) preserve its mechanical properties even when being exposed to high temperature processes.

Keywords: Aluminum alloys, chemical composition, heat treatment, automotive forms

\section{INTRODUCTION}

Aluminum alloys are widely used in number of industries for their unique mechanical properties. In order to satisfy industrial demands, new alloys are developed. With knowledge of the effect of chemical composition on mechanical properties of final alloys many researchers focused their experiments on this field of study [15].

Alloying elements were chosen based on following literature sources. Copper increases ability of precipitation hardening due to creation of intermetallic phase $\mathrm{CuAl}_{2}$. [6] Nickel makes intermetallic phases stabile within high temperature. Manganese decreases the negative impact of iron content. It also creates an intermetallic phase $\alpha-\mathrm{Al}_{15}(\mathrm{FeMn})_{3} \mathrm{Si}_{2}$ (Chinese script) [8]. Magnesium together with silicon creates intermetallic phase $\mathrm{Mg}_{2} \mathrm{Si}$ increasing mechanical properties (hardness and strength) after heat treatment process [15]. Silicon content reaching eutectic point improves casting properties. Modifiers for changing morphology of eutectic silicon particles in hypoeutectic silumins are strontium, antimony and calcium [2,3,16].

Based on information mentioned above [6, 7, 8, 14], the new alloy AlSi9CuNiMnMg was developed. In order to improve mechanical properties, aluminum alloys are usually heat treated. Therefore several heat treatment processes were examined and their effects were evaluated. Main aim of this research is to design new aluminum alloy and heat treatment process that can replace nowadays material for tire pressure moulds within local automotive company. 


\section{EXPERIMENT}

The new alloy was developed as an improvement of AISi7Mg0.3 alloy (EN AC 42 100) in relation to its usage. Alloy was used for casting form segments for tires pressing. Each of the moulds for tire pressing was made from 8 - 32 segments (depending on tires size). Castings (Figure 1) were produced by low pressure die casting technology. Batch of melt was dosed in furnace in $500 \mathrm{~kg}$ weight. The melt was purified by the addition of refining salt. The reduction of the gas content (gaseous impurities) in the melt was performed by FDU technology. After purifying, the melt was transferred in die during the fill stalk (made by centrifugal casting from cast iron) under the pressuring gas. Solidification of the alloy in die was performed under 0.66 MPa pressure. Two segments mould made from developed alloy are show in Figure 1 a).

During the research, several variants of castings were produced using low pressure die casting technology. The individual variants of castings differed in chemical composition (different content of $\mathrm{Si}, \mathrm{Cu}, \mathrm{Ni}, \mathrm{Mn}$ and $\mathrm{Mg}$ and use of different silumins modifiers $-\mathrm{Sr}, \mathrm{Sb}$ and $\mathrm{Ca}$ ).

The second phase of the research optimized the heat treatment parameters. The target of research was to develop new Al-Si alloy with high mechanical properties (even at high temperature) while maintaining good technological properties (castability and machinability).

The investigation of the mechanical properties of the alloy was carried out by measuring the hardness and microhardness and the static tensile test (at 20, 170 and $250{ }^{\circ} \mathrm{C}$ temperature). Alloy microstructure was analysed via light and scanning electron microscopy. Samples for the static tensile test within the casting (mould segment) are schematically indicated in Figure $\mathbf{1} \mathbf{b}$ ).
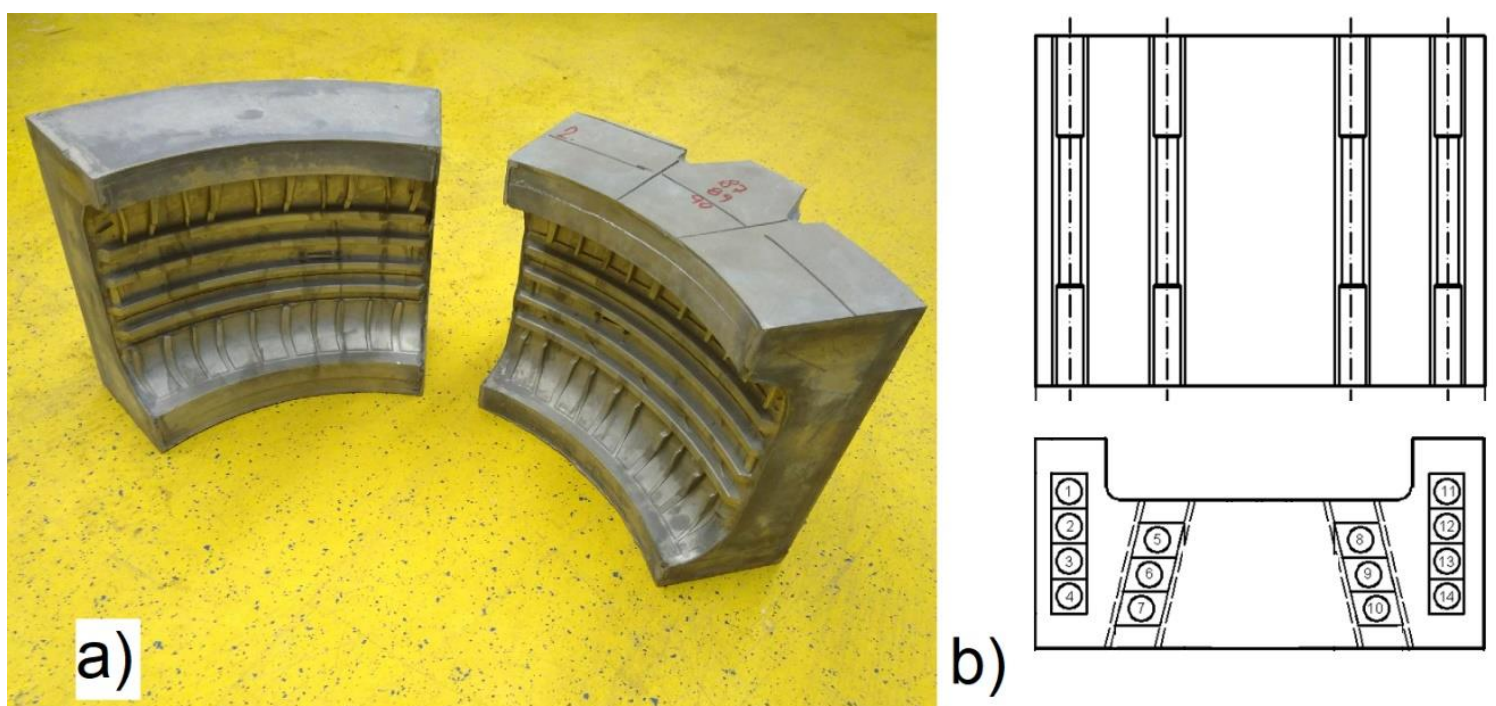

Figure 1 Example of analyzed samples, a) castings of segments, b) samples for static tensile test

\section{RESULTS AND DISCUSSION}

The microstructure of developed alloy corresponds to microstructure of hypoeuctectic silumins. Microstructure is created by dendritic cell of solid solution (bright fields). In interdendritic space is eutectic excluded (consisting of solid solution and eutectic silicon particles). In the unmodified state, silicon is precipitated in the form of hexagonal plates.

The addition of nickel to the alloy caused the formation of intermetallic phases of the Al-Si-Cu-Ni type and $\mathrm{AINi}_{3}$ in the microstructure. Polycomponent intermetallic phases type of $\mathrm{Al}-\mathrm{Si}-\mathrm{Cu}-\mathrm{Ni}$ are captured in Figure 2 (highlighted by red colour). 

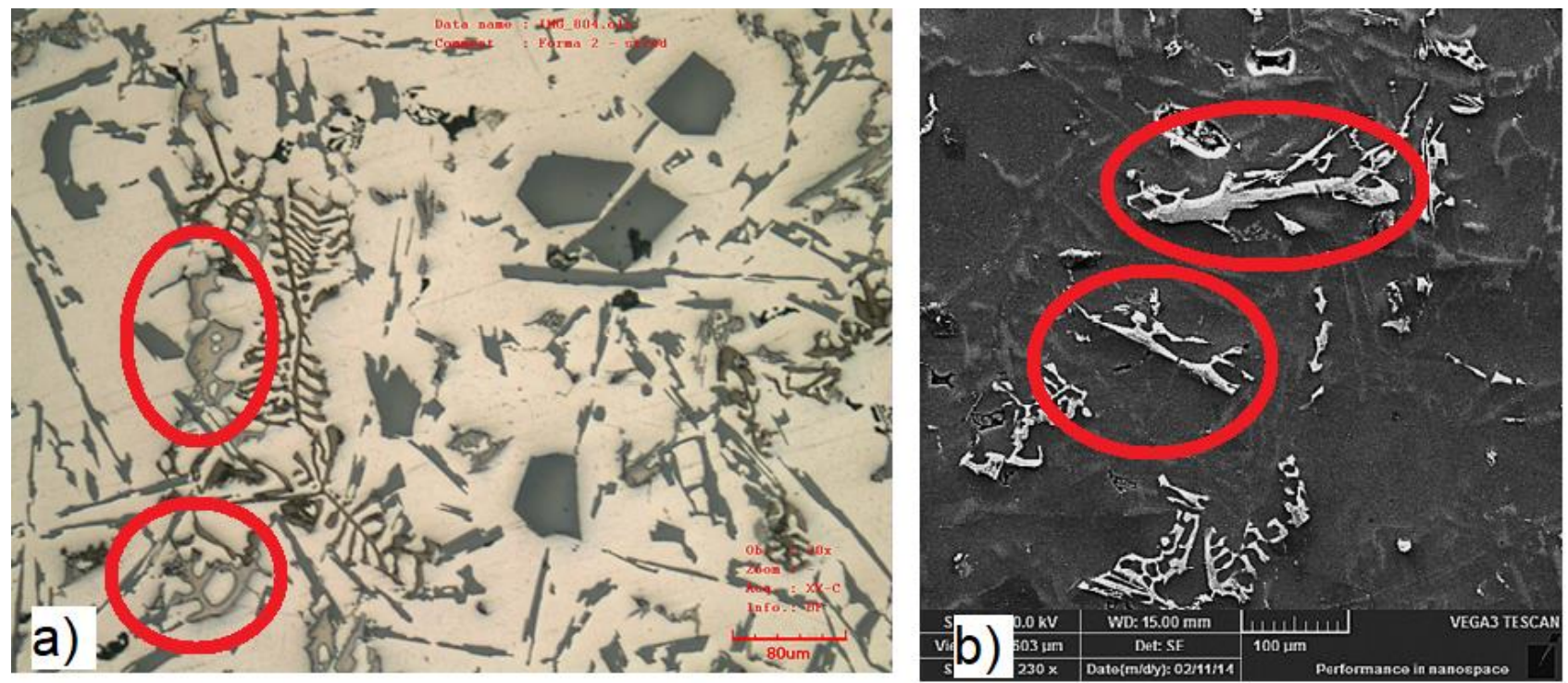

Figure 2 Intermetallic phases type of Al-Si-Cu-Ni, a) light microscopy, b) SEM

Manganese in alloy caused the iron to bind to the intermetallic phase $\alpha-\mathrm{Al}_{15}(\mathrm{FeMn})_{3} \mathrm{Si}_{2}$ (Chinese script). Precisely the addition of manganese prevented the formation of $\beta$-AlFeSi (in the shape of needles which significantly reduces mechanical properties). These intermetallic phases are captured in Figure 3.
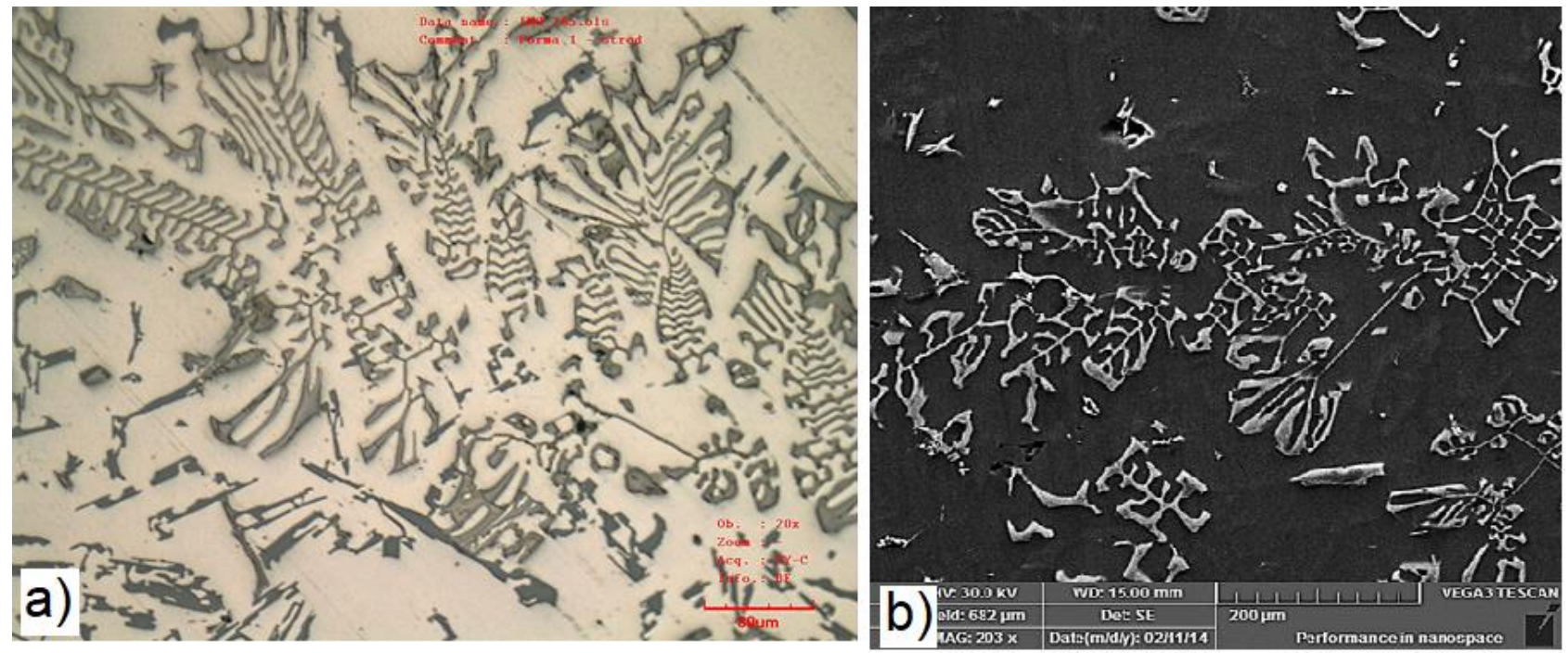

Figure 3 Intermetallic phases type of Al-Si-Cu-Ni, a) light microscopy, b) SEM

Alloy strontium, antimony and calcium were used as modifiers of the newly developed. Detail of eutectic silicon particle after modification is captured in Figure 4 (a) 0.03 wt\% Sr, b) 0.12 wt.\% Sb, c) 0.20 wt.\% Ca). The picture shows a difference in the morphology of eutectic silicon particles under the influence of individual modifiers. Addition of strontium $(0.03 \mathrm{wt} \%)$ changes eutectic silicon morphology into shape of fibers (round cross section with diameter in the order of units of micrometers and length in tens of micrometers. Use of antimony as a modifier $(0.12 \mathrm{wt} \%)$ incurred solidification of eutectic silicon in form of fine lamels with rounded edges. Modification of alloy by calcium $(0.20 \mathrm{wt} \%)$ incurred eutectic silicon particles in form tiny plates (with an edge length of approximately ten micrometers). 

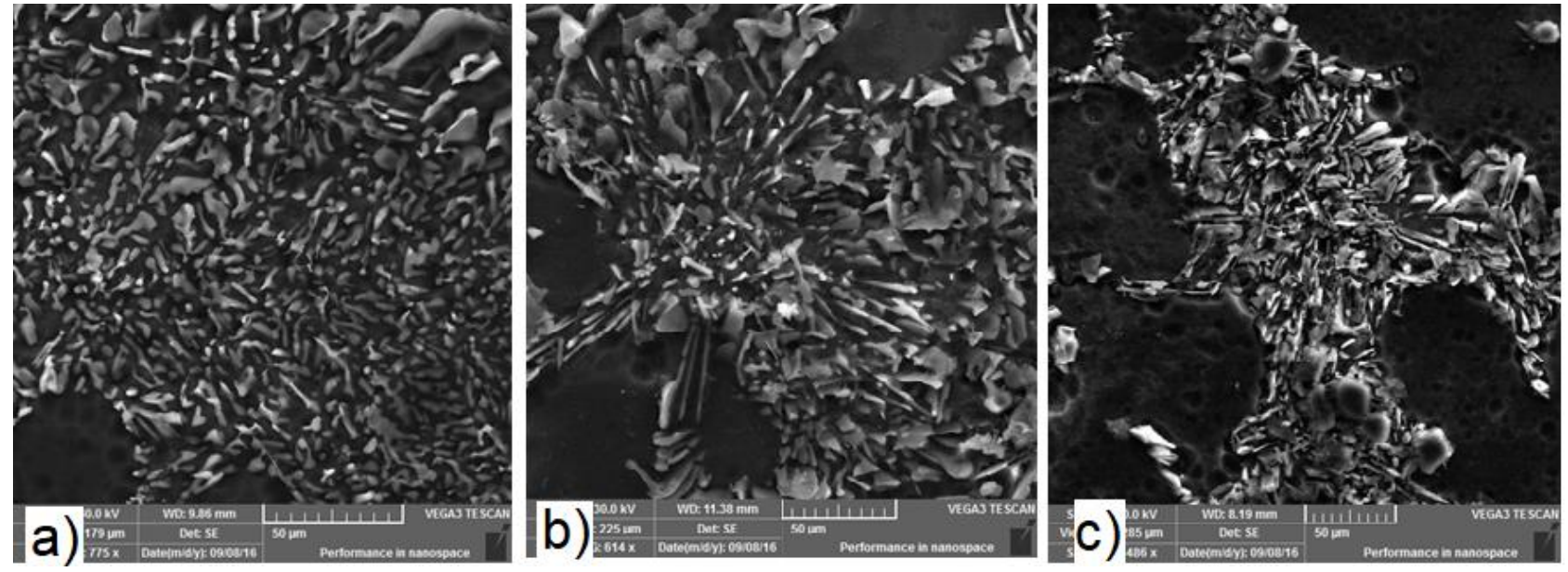

Figure 4 Details of eutectic silicon after modification: a) $0.03 \mathrm{wt} \% \mathrm{Sr}$, b) $0.12 \mathrm{wt} \% \mathrm{Sb}, \mathrm{c}) 0.20 \mathrm{wt} \% \mathrm{Ca}$

The addition of alloying elements led to the desired changes in the microstructure of the alloy. The addition of copper and nickel led to the formation of polycomponent intermetallic phases enabling an increase in mechanical properties through heat treatment and their maintenance at high temperatures. Manganese in the alloy caused iron to bind to coveted intermetallic phases ( $\alpha$-phase).

Based on changes in the microstructure caused by the addition of alloying elements the chemical composition of the alloy listed in Table 1 was proposed.

Table 1 Chemical composition of developed alloy

\begin{tabular}{|c|c|c|c|c|c|c|}
\hline Element & $\mathbf{S i}$ & $\mathbf{C u}$ & $\mathbf{N i}$ & $\mathbf{M n}$ & $\mathbf{M g}$ & $\mathbf{S r}$ \\
\hline Content $(\mathrm{wt} \%)$ & $8.5-10$ & $0.6-1.2$ & $0.6-1.0$ & $0.3-0.7$ & $0.3-0.5$ & $0.03-0.05$ \\
\hline
\end{tabular}

The heat treatment process applied upon developed alloy consisted of homogenization and subsequent artificial aging. As starting point for heat treatments parameters of new developed alloys were used heat treatment parameters of $\mathrm{AISi} \mathrm{Mg} 0.3$ and $\mathrm{AISi} 12 \mathrm{CuNi}$ alloy. Variable in heat treatment process was homogenization temperature and temperature of artificial aging. Five variants of parameters were chosen for heat treatment. Homogenization of samples was realized at temperature between 490 and $530^{\circ} \mathrm{C}$ (hold on for 2 hours). All samples were quenched in water at temperature $50^{\circ} \mathrm{C}$. Artificial aging of samples realized at temperature between 140 and $190^{\circ} \mathrm{C}$ (hold on for 6 hours). The parameters of the individual heat treatment variants are recorded in Table 2. Table 2 shows also the values of ductility, tensile strength and hardness (Brinell and Vickers). The parameters of Variant 1 were the optimal parameters of heat treatment (maximum values of the investigated mechanical properties).

Table 2 Mechanical properties of developed alloy after heat treatment $(\mathrm{HT})$

\begin{tabular}{|c|c|c|c|c|c|c|}
\hline Variant of HT & Homogenization $\left({ }^{\circ} \mathrm{C}\right)$ & Artificial aging $\left({ }^{\circ} \mathbf{C}\right)$ & $\boldsymbol{A}(\%)$ & $\boldsymbol{R m}(\mathrm{MPa})$ & $\mathbf{H B W}(2.5 / 62.5 / 10)$ & $\mathbf{H V}(0.02)$ \\
\hline $\mathbf{1}$ & 530 & 170 & 4.1 & 286 & 144 & 134 \\
\hline $\mathbf{2}$ & 510 & 140 & 4.0 & 247 & 126 & 112 \\
\hline $\mathbf{3}$ & 510 & 190 & 3.9 & 264 & 131 & 133 \\
\hline $\mathbf{4}$ & 490 & 140 & 4.1 & 252 & 125 & 125 \\
\hline $\mathbf{5}$ & 490 & 190 & 4.0 & 262 & 125 & 118 \\
\hline
\end{tabular}


Results of static tensile test (ductility and ultimate tensile strength) performed at different temperature are recorded in Table 3. From the obtained data it is evident that the strength limit of the developed alloy is maintained up to a temperature of $250^{\circ} \mathrm{C}$.

Table 3 Ductility and ultimate tensile strength developed alloy at different temperature

\begin{tabular}{|c|c|c|}
\hline Temperature $\left({ }^{\circ} \mathrm{C}\right)$ & $\boldsymbol{A}(\%)$ & $\boldsymbol{R m}(\mathrm{MPa})$ \\
\hline $\mathbf{2 0}$ & 5.4 & 292 \\
\hline $\mathbf{1 7 0}$ & 5.8 & 291 \\
\hline $\mathbf{2 5 0}$ & 7.4 & 300 \\
\hline
\end{tabular}

\section{CONCLUSION}

Based on the described research, a new alloy for moulds was patented. New hypoeutectic silumins with original chemical composition (alloyed with copper, nickel, manganese and magnesium) is able to be used as material for moulds for tires pressing. Chemical composition and optimized heat treatment parameters newly developed alloy provide high mechanical properties in normal and in increased temperature. The newly developed alloy has become part of the production portfolio of a company producing moulds for tire pressing as a replacement for AlSi7Mg0.3 alloy.

\section{ACKNOWLEDGEMENTS}

\section{This research was supported via internal postdoc grant within Jan Evangelista Purkyne University in Usti nad Labem.}

\section{REFERENCES}

[1] MICHNA, Š., CAIS, J. EP 3124632: Aluminum alloy in particular for the production of mould segment castings for forming types and the method of heat treatment of mould segment.

[2] STŘIHAVKOVÁ, E., WEISS, V., MICHNA, Š. Study of the structure and fluidity of alloy of the Al-Si-Mg system with a different calcium content. Metallurgist. January 2013, vol. 56, iss. 9-10, pp. 708-713.

[3] MEDLEN, D., BOLIBRUCHOVA, D. Effect of Sb-modification on the microstructure and mechanical properties of secondary alloy 319. Archives of Metallurgy and Materials. 2016, vol. 61, no. 2, pp. 553-558.

[4] KNUUTINEN, A., NOGITA, K., MCDONALD, S., DAHLE, A. Modification of Al-Si alloys with Ba, Ca, Y and Yb. Journal of Light Metals. 2001, pp. 229-240.

[5] GANESAN, M., THUINET, L., DYE, D., LEE, P.D. Quantification of microsegregation in cast Al-Si-Cu alloys. Metallurgical and Materials Transactions B. August 2007, vol. 38, iss. 4, pp. 557-566. ISSN 1073-5615.

[6] LI, Z., SAMUEL, A. M., SAMUEL, F. H., RAVINDRAN, C., VALTIERRA, S. Effect of alloying elements on the segregation and dissolution of $\mathrm{CuAl}_{2}$ phase in Al-Si-Cu 319 alloys. Journal of Materials Science. March 2003, vol. 38 , iss. 6, pp. 1203-1218.

[7] MOUSTAFA, M. A., SAMUEL, F. H., DOTY, H. W. Effect of solution heat treatment and additives on the microstructure of Al-Si (A413.1) automotive alloys. Journal of Materials Science. November 2003, vol. 38, iss. 22, pp. 4507-4522.

[8] LIU, L., MOHAMED, A.M.A., SAMUEL, A.M., SAMUEL, F.H., DOTY, H.W., VALTIERRA S. Precipitation of $\beta$ Al5FeSi phase platelets in Al-Si based casting alloys. Metallurgical and Materials Transactions A. October 2010, vol. 40, iss. 10, pp. 2457-2469.

[9] ELSHARKAWI, E. A., SAMUEL, E., SAMUEL, A. M., SAMUEL, F. H. Effects of Mg, Fe, Beadditions and solution heat treatment on the $\pi-A I M g F e S i$ iron intermetallic phase in Al-7Si-Mg alloys. Journal of Materials Science. March 2010, vol. 45, iss. 6, pp. 1528-1539. 
[10] SHABESTARI, S.G., SHAHRI, F. Influence of modification, solidification conditions and heatt reatment on the microstructure and mechanical properties of A356 aluminum alloy. Journal of Materials Science. March 2004, vol. 39 , iss. 6 , pp. 2023-2032.

[11] LIU, L., SAMUEL, A.M., SAMUEL, F.H., DOTY, H.W., VALTIERRA, S. Characteristics of $\alpha$-dendritic and eutectic structures in Sr-treated Al-Si casting alloys. Journal of Materials Science. January 2004, vol. 39, iss. 1, pp. 215-224.

[12] DAHLE, A.K., NOGITA, K., MCDONALD, S.D., ZIMDEL, J.W., HOGAN, L.M. Eutectic nucleation and growth in hypoeutectic Al-Si alloys at different strontium levels. Metallurgical and Materials Transactions A. April 2001, vol. 32 , iss. 4, pp. 949-960.

[13] SUN, Y., WANG, Q., GENG, H. Effects of complex modificating technique on microstructure and mechanical properties of hypereutectic Al-Si alloys. Journal of Materials Science. March 2012, vol. 47, iss. 5, pp. $2104-2109$.

[14] OSÓRIO, W. R, CHEUNG, N., SPINELLI, J. E., GOULART, P. R., GARCIA, A. The effects of a eutectic modifier on microstructure and surface corrosion behavior of Al-Si hypoeutectic alloys. Journal of Solid State Electrochemistry, October 2007, vol. 11, iss. 10, pp. 1421-1427.

[15] MOHAMED, A.M.A., SAMUEL, F.H., SAMUE, L.A.M., DOTY, H.W., VALTIERRA, S. Influence of tin addition on the microstructure and mechanical properties of Al-Si-Cu-Mg and Al-Si-Mg Casting Alloys. Metallurgical and Materials Transactions A. March 2003, vol. 39, iss. 3, pp. 490-501.

[16] ELSEBAIE, O., SAMUEL, A.M., SAMUEL, F. H. Effects of Sr-modification, iron-based intermetallics and aging treatment on the impact toughness of $356 \mathrm{Al}-\mathrm{Si}-\mathrm{Mg}$ alloy. Journal of Materials Science. May 2011, vol. 46, iss. 9, pp. 3027-3045. 